\title{
On the Destiny of (Copper) Species
}

$\mathbf{T}$

he study by Hueting et al. (1) in this issue of The Journal of Nuclear Medicine reporting the biodistribution of the putative hypoxia tracer ${ }^{64} \mathrm{Cu}$-diacetyl-bis(N4methylthiosemicarbazonate) $\quad\left({ }^{64} \mathrm{Cu}\right.$-ATSM) and that of its precursor ${ }^{64} \mathrm{Cu}$-acetate in mice bearing CaNT or EMT6 xenograft tumors is a timely and valuable contribution to the fields of both hypoxia imaging and metal-based radiopharmaceuticals. Although several groups have evaluated the biodistribution of ${ }^{64} \mathrm{Cu}$-ATSM in tumorbearing mice, this study is apparently the first to report a detailed comparison of the biodistribution of the 2 compounds, including the effect of hypoxia on their in vivo distribution.

Hueting et al. report that ${ }^{64} \mathrm{Cu}-\mathrm{ATSM}$ tumor cell uptake in vitro is much higher than that of ${ }^{64} \mathrm{Cu}$-acetate and that ${ }^{64} \mathrm{Cu}$ ATSM shows hypoxia selectivity in vitro, as does ${ }^{64} \mathrm{Cu}$-acetate, although to a lesser degree. It is the in vivo data, however, that

\section{See page 128}

have significant implications for ${ }^{64} \mathrm{Cu}$ radiopharmaceuticals based on bis(thiosemicarbazone) complexes. In vivo, the 2 compounds demonstrate similar tissue distribution. Although there are differences in some tissues at $15 \mathrm{~min}$ after injection, the differences are minimal at $2 \mathrm{~h}$ after injection, and at $16 \mathrm{~h}$ after injection the distribution of the 2 tracers is essentially identical. Interestingly, this convergence parallels the results of the EF5 study in which the ex vivo tracer distribution of both ${ }^{64} \mathrm{Cu}$-ATSM and

Received Oct. 19, 2013; revision accepted Nov. 12, 2013.

For correspondence or reprints contact: Jason L.J. Dearling, Division of Nuclear Medicine and Molecular Imaging, Department of Radiology, Boston Children's Hospital, 300 Longwood Ave., Boston, MA 02115.

E-mail: jason.dearling@childrens.harvard.edu Published online Dec. 12, 2013.

COPYRIGHT (C) 2014 by the Society of Nuclear

Medicine and Molecular Imaging, Inc.

DOI: 10.2967/jnumed.113.132480
${ }^{64} \mathrm{Cu}$-acetate show increasing agreement with the EF5 results over time. The converging biodistribution results are not surprising in light of the stability studies that show a $50 \%$ decrease in octanol-extractable ${ }^{64} \mathrm{Cu}$-ATSM after $2 \mathrm{~h}$ in vitro and approximately a $100 \%$ decrease by $2 \mathrm{~h}$ in vivo. It is also interesting to note the large discrepancy between the in vivo and in vitro protein-binding data for ${ }^{64} \mathrm{Cu}$ ATSM, which suggests there is some process occurring in vivo that is removing ${ }^{64} \mathrm{Cu}$ from the ${ }^{64} \mathrm{Cu}$-ATSM complex that is not reflected in the in vitro protein-binding results. The striking similarity between the data for ${ }^{64} \mathrm{Cu}$-acetate and ${ }^{64} \mathrm{Cu}$-ATSM presented in this paper thus brings into question the role of ATSM in targeting the radiocopper to hypoxic cells in vivo.

There are multiple reports of the use of ${ }^{64} \mathrm{Cu}$-ATSM for imaging hypoxia, often including comparisons with gold standards of extreme tumor hypoxia (typically ex vivo nitroimidazole-adduct immunodetection) (2-4). However, these comparisons have often questioned the general applicability of ${ }^{64} \mathrm{Cu}$-ATSM as a tracer for imaging tissue hypoxia because the tumor microdistribution of ${ }^{64} \mathrm{Cu}$-ATSM changes over time in relation to reference hypoxia markers, the degree of agreement between the two varies significantly between tumor lines, and the extent of uptake of ${ }^{64} \mathrm{Cu}$-ATSM by hypoxic cells in vitro varies widely (5). In light of these studies and the current report by Hueting et al., it seems reasonable to conclude that the variation in tumor microdistribution of ${ }^{64} \mathrm{Cu}$-ATSM and the apparent lack of consistency of hypoxic tissue selectivity of ${ }^{64} \mathrm{Cu}$-ATSM may be due to differences in metabolism of radiocopper by the host organism and the tumor cells rather than by differences in tumor hypoxia.

The most obvious comparison for the current data is with that of Lewis et al. (6) who measured the biodistribution of ${ }^{64} \mathrm{Cu}$ ATSM and ${ }^{64} \mathrm{Cu}$-pyruvaldehyde-bis(N4-methylthiosemicarbazonate) $\left({ }^{64} \mathrm{Cu}-\mathrm{PTSM}\right)$ at early time points (up to $40 \mathrm{~min}$ ) using a similar model system. It is notable that in this study, ${ }^{64} \mathrm{Cu}$-ATSM had higher uptake than ${ }^{64} \mathrm{Cu}$-PTSM in organs that are normally hypoxic, such as the liver, and lower uptake than ${ }^{64} \mathrm{Cu}-\mathrm{PTSM}$ in more oxygenated organs, such as the lung, brain, and heart. From these results and those of Hueting et al., one could infer that at early time points ${ }^{64} \mathrm{Cu}$-ATSM distribution is to some extent influenced by tissue hypoxia but that this may not be the primary determinant of its longer-term biodistribution. The overall pattern of distribution of ${ }^{64} \mathrm{Cu}$-ATSM in these 2 studies is similar (with a Pearson correlation coefficient of $>0.9$ in 7 common tissues), though the absolute values differ. This discrepancy is more likely due to differences in data handling between the 2 laboratories than in the models used, the only major distinction being the strains of mice used in each study.

Although it has been suggested that $\mathrm{Cu}$-ATSM could be used as an agent for hypoxia detection, the greatest focus of its clinical use has been in the stratification of cancer patients for therapy with high tumor uptake of the tracer, indicating a poor prognosis (7-9). The relationship between higher uptake of a putative hypoxia tracer and prognosis appeared to be reasonable because tumors with a greater degree of tumor hypoxia tend to be more aggressive in terms of growth and metastasis (10), although the mechanism of uptake remains unknown and tumor uptake cannot now be solely ascribed to hypoxia. The results of Hueting et al. and those of similar studies with ${ }^{64} \mathrm{Cu}-\mathrm{Cl}$ and ${ }^{64} \mathrm{Cu}$-acetate suggest that it is time to reevaluate the mechanisms underlying these observations, of what we may learn from them about tumor metabolism, and of how future imaging agents can be better designed for improved tumor detection and characterization. It would also be worthwhile to evaluate the more easily prepared ${ }^{64} \mathrm{Cu}$-acetate as an agent for patient stratification. These results also serve to emphasize the importance of the chelator in the development of metalloradiopharmaceuticals and of using chelators that form stable complexes and verifying their stability, both in vitro and in vivo.

Whatever the findings of future studies of the mechanism of ${ }^{64} \mathrm{Cu}$-ATSM distribution and that of other metal-essential radiotracers, this study is an important step in the development and evolution of such imaging agents. 


\section{Jason L.J. Dearling}

Boston Children's Hospital

Boston, Massachusetts

Harvard Medical School

Boston, Massachusetts

Alan B. Packard

Boston Children's Hospital

Boston, Massachusetts

Harvard Medical School

Boston, Massachusetts

\section{REFERENCES}

1. Hueting R, Kersemans V, Cornelissen B, et al. A comparison of the behavior of ${ }^{64} \mathrm{Cu}$-acetate and ${ }^{64} \mathrm{Cu}$-ATSM in vitro and in vivo. $\mathrm{J} \mathrm{Nucl} \mathrm{Med}$. 2014;55:128-134.

2. O'Donoghue JA, Zanzonico P, Pugachev A, et al. Assessment of regional tumor hypoxia using ${ }^{18} \mathrm{~F}$ - fluoromisonidazole and ${ }^{64} \mathrm{Cu}$ (II)-diacetyl-bis $\left(\mathrm{N}_{4}\right.$ methylthiosemicarbazone) positron emission tomography: comparative study featuring microPET imaging, $\mathrm{PO}_{2}$ probe measurement, autoradiography, and fluorescent microscopy in the R3327-AT and $\mathrm{FaDu}$ rat tumor models. Int $J$ Radiat Oncol Biol Phys. 2005;61:1493-1502.

3. Yuan H, Schroeder T, Bowsher JE, Hedlund LW, Wong T, Dewhirst MW. Intertumoral differences in hypoxia selectivity of the PET imaging agent ${ }^{64} \mathrm{Cu}$ (II)diacetyl-bis $\left(\mathrm{N}_{4}\right.$-methylthiosemicarbazone). $\mathrm{J} \mathrm{Nucl}$ Med. 2006;47:989-998.

4. McCall KC, Humm JL, Bartlett R, Reese M, Carlin S. Copper-64-diacetyl-bis(N(4)-methylthiosemicarbazone) pharmacokinetics in $\mathrm{FaDu}$ xenograft tumors and correlation with microscopic markers of hypoxia. Int J Radiat Oncol Biol Phys. 2012;84:e393-e399.

5. Burgman P, O'Donoghue JA, Lewis JS, Welch MJ, Humm JL, Ling CC. Cell line-dependent differences in uptake and retention of the hypoxia-selective nuclear imaging agent Cu-ATSM. Nucl Med Biol. 2005;32:623-630.
6. Lewis JS, McCarthy DW, McCarthy TJ, Fujibayashi Y, Welch MJ. Evaluation of ${ }^{64} \mathrm{Cu}-$ ATSM in vitro and in vivo in a hypoxic tumor model. J Nucl Med. 1999;40:177-183.

7. Dehdashti F, Mintun MA, Lewis JS, et al. In vivo assessment of tumor hypoxia in lung cancer with ${ }^{60} \mathrm{Cu}$-ATSM. Eur J Nucl Med Mol Imaging. 2003;30:844-850.

8. Dehdashti F, Grigsby PW, Lewis JS, Laforest R, Siegel BA, Welch MJ. Assessing tumor hypoxia in cervical cancer by PET with ${ }^{60} \mathrm{Cu}$-labeled diacetylbis( $\mathrm{N}_{4}$-methylthiosemicarbazone). $\mathrm{J} \mathrm{Nucl} \mathrm{Med}$. 2008;49:201-205.

9. Dietz DW, Dehdashti F, Grigsby PW, et al. Tumor hypoxia detected by positron emission tomography with ${ }^{60} \mathrm{Cu}$-ATSM as a predictor of response and survival in patients undergoing neoadjuvant chemoradiotherapy for rectal carcinoma: a pilot study. Dis Colon Rectum. 2008;51:1641-1648.

10. Vaupel P. Metabolic microenvironment of tumor cells: a key factor in malignant progression. Exp Oncol. 2010;32:125-127. 